\title{
Hubungan tingkat kepercayaan diri dengan obesitas pada siswa SMA Negeri 1 Manado
}

\author{
${ }^{1}$ Dianita L. Sitepu \\ ${ }^{2}$ Hendri Opod \\ ${ }^{3}$ Cicilia Pali
}

\author{
${ }^{1}$ Kandidat Skripsi Fakultas Kedokteran Universitas Sam Ratulangi Manado \\ ${ }^{2}$ Bagian Psikologi Fakultas Kedokteran Universitas Sam Ratulangi Manado \\ Email: dianitalestarisitepu@gmail.com
}

\begin{abstract}
Obesity is excessive accumulation of fat in adipose tissue that can cause health problems. In teenagers, obesity will also affect the psychosocial development including self confidence. Obese teenagers shunned by his/her friends have a tendency to experience a sense of great despair or lack of confidence. Self confidence is to believe in the capacity and ability of self and is seen as a positive personality. This study aimed to obtain the correlation level of self-confidence with obesity in students at SMA Negeri 1 Manado. This was a correlational srudy with a cross sectional design. Samples were 62 students gathered at the same time. Sampling was done by using purposive sampling technique. The results showed that confidence levels in obese students were high category in 40 students (65\%). The correlation test of Pearson Product Moment showed a coefficient of $r_{x y}=-0.224$ and a significance value of $p=0.080$. Conclusion: There was no significant relationship between self confidence and obesity.
\end{abstract}

Keywords: obesity, self confidence

\begin{abstract}
Abstrak: Obesitas adalah suatu akumulasi lemak berlebihan dalam jaringan adiposa yang dapat menimbulkan gangguan kesehatan. Pada kelompok remaja, obesitas akan berpengaruh pula pada perkembangan psikososial termasuk kepercayaan diri. Remaja dengan obesitas yang dijauhi oleh teman-temannya memiliki kecenderungan untuk mengalami rasa putus asa yang besar atau kurang percaya diri. Kepercayaan diri adalah percaya pada kapasitas kemampuan diri dan terlihat sebagai kepribadian yang positif. Penelitian ini bertujuan untuk melihat hubungan tingkat kepercayaan diri dan obesitas pada siswa di SMA Negeri 1 Manado. Jenis penelitian ini korelasional dengan desain potong lintang. Sampel berjumlah 62 siswa/i yang dikumpulkan pada waktu yang bersamaan. Pengambilan sampel dilakukan dengan menggunakan teknik purposive sampling. Hasil penelitian menunjukkan tingkat kerpecayaan diri pada remaja yang obesitas berada pada kategori tinggi sebanyak 40 orang (65\%). Hasil uji korelasi Pearson Product Moment menunjukkan nilai koefisien korelasi sebesar $r_{x y}=-0,224$ dan nilai signifikansi $p=0,080$. Simpulan: Tidak terdapat hubungan bermakna antara kepercayaan diri dan obesitas.
\end{abstract}

Kata kunci: obesitas, kepercayaan diri

Obesitas adalah akumulasi lemak dalam jaringan adiposa yang abnormal atau berlebihan hingga mencapai suatu taraf yang dapat menimbulkan gangguan kesehatan. Obesitas dipengaruhi oleh beberapa faktor yaitu: asupan makanan, mekanisme neuroendokrin, genetik, faktor sosial dan gaya hidup. ${ }^{1}$ Obesitas dapat terjadi baik pada anak-anak hingga usia dewasa, tidak terkecuali pada remaja. Istilah remaja (adolescence) berarti tumbuh menjadi dewasa atau perkembangan 
menuju kematangan. Remaja merupakan suatu perubahan transisi antara masa anakanak dan masa dewasa, yang melibatkan perubahan fisik, kognitif, dan psikososial. ${ }^{2}$

Prevalensi obesitas pada anak dan remaja mengalami peningkatan di berbagai negara tidak terkecuali Indonesia. Tingginya prevalensi obesitas disebabkan oleh pertumbuhan urbanisasi dan perubahan gaya hidup seseorang termasuk pola makan atau asupan energi. Berdasarkan data dari World Health Organization (2015) angka kejadian obesitas di dunia telah meningkat lebih dari dua kali lipat sejak tahun 1980. Pada tahun 2014, lebih dari 1,9 milyar orang dewasa dengan kelebihan berat badan (overweight). Dari angka ini terdapat 600 juta orang dengan obesitas. Secara keseluruhan, terdapat $13 \%$ populasi dewasa (11\% lakilaki dan 40\% wanita) di dunia dengan obesitas. ${ }^{3}$ Hasil Riset Kesehatan Dasar (Riskesdas) Indonesia tahun 2011, angka obesitas pada remaja usia 18 tahun tercatat sebanyak $27,1 \%{ }^{4}$

Di kalangan remaja masalah obesitas menjadi masalah tersendiri. Hal ini diakibat-kan oleh adanya ciri masa remaja sebagai masa pencarian jati diri dan remaja mulai memperhatikan penampilannya sebagai penunjang interaksi sosial. Masa remaja ini pada akhirnya membawa permasalahan obesitas tidak hanya mengenai keadaan fisik saja tetapi lebih cenderung ke arah psikologis, seperti adanya pandangan wanita dan pria bertubuh kurus atau langsing, ideal atau berotot kekar merupakan sosok yang wajib dimiliki sebagai salah satu faktor penunjang dalam interaksi sosial. Dalam sebuah penelitian juga memperlihatkan bahwa remaja dengan obesitas yang dijauhi oleh teman-temannya memiliki kecenderungan untuk mengalami rasa putus asa yang besar atau kurang kepercayaan diri. $^{5}$

Kepercayaan diri pada setiap individu akan berbeda, hal ini dipengaruhi oleh sejauh mana penerimaan masyarakat pada individu. Jika mereka merasa dirinya diterima maka akan muncul perasaan aman dan nyaman untuk melakukan segala hal yang mereka inginkan. Kepercayaan diri merupakan pandangan sikap dan keyakinan remaja dalam menghadapi suatu tugas dan pekerjaan. Tidak adanya percaya diri, seseorang tidak dapat mengembangkan potensi-potensi yang dimilikinya dan menjadi manusia yang utuh dalam kehidupan masyarakat. Kepercayaan diri akan memperkuat motivasi mencapai keberhasilan, karena semakin tinggi kepercayaan terhadap kemampuan diri sendiri, semakin kuat pula semangat untuk menyelesaikan segala pekerjaannya. Kepercayaan diri juga membawa kekuatan dalam menentukan langkah dan merupakan faktor utama dalam mengatasi suatu masalah. ${ }^{6}$

\section{METODE PENELITIAN}

Jenis penelitian ini ialah korelasional dengan desain potong lintang. Penelitian dilakukan pada bulan Oktober-Desember 2015 di SMA Negeri 1 Manado. Subjek penelitian diambil dari seluruh siswa/i SMA Negeri 1 Manado yang obes dan memenuhi kriteria inklusi dan eksklusi. Jumlah subyek obes sebanyak 62 siswa/i. Pengambilan sampel menggunakan purposive sampling. Analisis data menggunakan teknik korelasi Pearson Product Moment dengan program SPSS 20 for Windows.

\section{HASIL PENELITIAN}

Pada penelitian ini usia responden berkisar 14-17 tahun, dan yang terbanyak pada usia 15 tahun (43\%) dengan jenis kelamin terbanyak perempuan 38 (62\%) (Tabel 1). Jumlah responden penelitian yang mengalami obesitas I sebanyak 20 (32\%) orang sedangkan obesitas II sebanyak 42 (68\%) orang. (Tabel 2).

Tabel 1. Distribusi responden berdasarkan jenis kelamin

\begin{tabular}{ccc}
\hline Jenis Kelamin & Responden & $(\%)$ \\
\hline Laki-laki & 24 & 38 \\
Perempuan & 38 & 62 \\
Total & 62 & 100 \\
\hline
\end{tabular}


Tabel 2. Distribusi Responden Obes berdasarkan IMT

\begin{tabular}{cccc}
\hline Kategori & $\begin{array}{c}\text { IMT } \\
\mathrm{kg} / \mathrm{m}^{2}\end{array}$ & $\begin{array}{c}\text { Responde } \\
\mathrm{n}\end{array}$ & $\%$ \\
\hline Obesitas I & $25,0-29,9$ & 20 & 32 \\
Obesitas II & $\geq 30,0$ & 42 & 68 \\
Total & & 62 & 100 \\
\hline
\end{tabular}

Pada penelitian ini dari 62 subjek obes yang memiliki kepercayaan diri tinggi sebanyak 40 orang; kepercayaan diri sedang 22 orang; sedangkan kepercayaan diri rendah tidak ada (Tabel 3). Berdasarkan hasil korelasi analisis uji korelasi Pearson Product Moment antara keperayaan diri dan obesitas pada siswa
SMA Negeri 1 Manado didapatkan hasil sebesar $r_{x y}=-0,224$ dengan nilai signifikansi $\mathrm{p}=0,080$, yang menunjukkan tidak terdapat hubungan antara kepercayaan diri dan obesitas (Tabel 4).

Tabel 3. Deskripsi Responden Berdasarkan Tingkat Kepercayaan Diri

\begin{tabular}{cccc}
\hline Keterangan & Range & $\begin{array}{c}\text { Jumlah } \\
\text { orang }\end{array}$ & $\%$ \\
\hline Rendah & $32-64$ & - & - \\
Sedang & $64-96$ & 22 & 35 \\
Tinggi & $96-128$ & 40 & 65 \\
\multicolumn{2}{c}{ Total } & 62 & 100 \\
\hline
\end{tabular}

Tabel 4. Hasil Korelasi Antara Kedua Variabel

\begin{tabular}{llcc}
\hline \multirow{3}{*}{ Obesitas } & & Obesitas & Kepercayaan Diri \\
\hline \multirow{2}{*}{ Kepercayaan Diri } & Pearson Correlation & 1 & -.224 \\
\cline { 2 - 4 } & Sig. (2-tailed) & 62 & .080 \\
\cline { 2 - 4 } & $\mathrm{N}$ & -.224 & 62 \\
\cline { 2 - 4 } & Pearson Correlation & .080 & 1 \\
\cline { 2 - 4 } & $\mathrm{N}$ & 62 & 62 \\
\hline
\end{tabular}

\section{BAHASAN}

Berdasarkan hasil penelitian korelasional pada siswa SMA Negeri 1 Manado tahun 2016 diperoleh 62 responden yang mengalami obesitas. Tingkat kepercayaan diri terbagi menjadi tiga kategori: kepercayaan diri tinggi sebesar 65\% (40 orang), sedang 35\% (22 orang), dan rendah tidak ada.

Hasil analisis tingkat kepercayaan diri siswa dengan obesitas di SMA Negeri 1 Manado yang terbanyak ialah tingkat kepercayaan diri tinggi sebanyak 40 orang (65\%), artinya pada tahap ini kepercayaan diri remaja sedang berkembang. Hal ini sesuai dengan penelitian yang menyatakan perkembangan rasa percaya diri seseorang berawal dari terbentuknya konsep diri yang positif pada masa pubertas awal. "Masa ini kepercayaan diri remaja ditandai dengan konsep diri yang positif" yaitu dimana seorang remaja mampu beradaptasi dengan lingkungan, mampu mengembangkan motivasi, bekerja keras untuk kemajuan serta yakin penuh terhadap diri sendiri. Konsep diri negatif pada remaja dapat disebabkan oleh faktor dari dalam diri dan faktor dari lingkungan yang kurang mendukung keadaan remaja tersebut misalnya kurang mendapat-kan kasih sayang dan tidak yakin akan diri sendiri. ${ }^{7}$ Penelitian yang dilakukan oleh Ata et al. menyatakan bahwa kepercayaan diri yang menurun selama masa remaja berkaitan dengan perubahan pada bentuk tubuh. Kepercayaan diri berhubungan dengan pikiran dan perasaan seseorang, yang dapat memberikan pengaruh terhadap mental dan keadaan fisik yang lebih buruk. Masa remaja merupakan masa kritis bagi pembentukan dan pandangan terhadap diri sendiri. $^{8}$

Obesitas merupakan salah satu kondisi yang dapat mempengaruhi kepercayaan diri 
seseorang. Pada Tabel 2, distribusi responden obes berdasarkan IMT didapatkan hasil bahwa sebesar 68\% (42 responden) mengalami obesitas tipe II. Hal ini sejalan dengan penelitian oleh French et al. ${ }^{9}$ tentang kepercayan diri dan perubahan IMT selama 3 tahun pada kelompok remaja menunjukkan hasil, kepercayaan diri yang rendah menjadi faktor psikologi terkait dengan perkembangan obesitas sehingga kepercayaan diri menjadi faktor yang penting untuk remaja dalam proses penurunan berat badan.

Penelitian mengenai penatalaksanaan dan tindakan lanjut untuk remaja obes yang dilakukan oleh Hoerr mendapatkan hasil kepercayaan diri meningkat pada remaja yang mengikuti program penurunan berat badan, hal ini menunjukkan hubungan yang signifikan antara obesitas dan tingkat kepercayaan diri. Dengan kata lain perubahan IMT dapat memengaruhi tingkat kepercayaan diri seseorang. ${ }^{9}$ National Longitudinal Survey of Youth (NLSY) di Amerika, Penelitian yang dilakukan Strauss ${ }^{10}$ juga pada anak remaja yang obes berusia 13-14 tahun menunjukkan penurunan tingkat kepercayaan diri. Penurunan tingkat kepercayaan diri terkait dengan peningkatan signifikan dari kesedihan, kegelisahan, dan kesepian. Di Inggris pada penelitian yang dilakukan Jackson et al. ${ }^{11}$ selain resiko kesehatan fisik yang berhubungan dengan obesitas, efek buruk juga terdapat pada kesejahteraan psikologis individu. Pada tahun 1985, National Institutes of Health memberikan perhatian pada obesitas berkaitan dengan beban psikologis yang besar. Didapatkan bukti bahwa individu dengan obesitas memiliki kualitas hidup yang rendah, tidak percaya diri dan memiliki peningkatan resiko depresi dan gangguan kejiwaan lainnya. ${ }^{11}$

Untuk tingkat kepercayaan diri berdasarkan jenis kelamin seperti pada Tabel 3, diperoleh 22 orang yang memiliki kepercayaan diri sedang, dimana sebesar $60 \%$ (13 orang) berjenis kelamin perempuan dan sebesar $40 \%$ (9 orang) berjenis kelamin laki-laki. Dalam penelitian yang dilakukan Griffiths et al. ${ }^{12}$ mengenai kepercayaan diri dan kualitas hidup pada anak dan remaja yang obesitas menunjukkan bahwa kepercayaan diri dipengaruhi oleh jenis kelamin dan suku bangsa. Perbedaan jenis kelamin membawa perbedaan rasa percaya diri seperti penelitian yang dilakukan di Australia menunjukkan remaja perempuan memiliki tingkat kepercayaan diri yang lebih rendah dibandingkan remaja laki-laki. Sama halnya dengan penelitian yang dilakukan Makinen et al. ${ }^{13}$ antara kepercayaan diri dan ketidak-puasan berat badan didapatkan korelasi yang negatif antara kedua jenis kelamin, namun korelasi tersebut lebih kuat pada remaja perempuan oleh karena remaja perempuan memiliki kepuasan jika mereka kekurangan berat badan dibandingkan kelebihan berat badan.

Berdasarkan hasil uji korelasi Pearson Product Moment antara kepercayaan diri dengan obesitas pada siswa SMA Negeri 1 Manado didapatkan hasil $\mathrm{r}_{\mathrm{xy}}=-0,224$ dan nilai signifikansi sebesar 0,080 dimana nilai tersebut lebih besar 0,05 yang merupakan nilai acuan, artinya tidak terdapat hubungan yang signifikan atau bermakna antara kepercayaan diri dan obesitas. Hal ini serupa dengan penelitian yang dilakukan Renman et al. ${ }^{14}$ pada remaja berusia 14-18 tahun, jumlah sampel 116 remaja (58 obesitas, 58 kontrol), yang terdiri dari 60 laki-laki dan 56 perempuan. Penelitian Renmann et al. menggunakan alat ukur "I think I am, Youth Self Report and a lifestyle questionnaire". Hasil penelitian Renman et al. ${ }^{14}$ menunjukkan tidak ada hubungan antara kepercayaan diri dengan obesitas karena hal ini dapat dipengaruhi oleh beberapa faktor sehingga terbentuklah individu yang percaya diri. Faktor-faktor yang dapat memengaruhi kepercayaan diri digolongkan menjadi dua, yaitu faktor internal dan faktor eksternal. Faktor internal meliputi konsep diri, harga diri, kondisi fisik dan pengalaman hidup contohnya misalnya seorang remaja mempunyai konsep diri yang positif terhadap diri sendiri, memiliki harga diri yang tinggi, bertindak mandiri dalam 
mengambil keputusan serta mempunyai pengalaman hidup yang baik seperti berlimpah kasih sayang dan perhatian dari orang tua maupun orang sekitar. Faktor eksternal yang juga mempengaruhi kepercayaan diri meliputi pendidikan, pekerjaan dan lingkungan dengan contoh seorang remaja memiliki prestasi yang membanggakan disekolah, disukai temanteman dalam pergaulan sehari-hari, pada lingkungan keluarga mendapatkan dukungan yang baik dan merasa nyaman, sehingga kondisi fisik bukan merupakan satu-satunya faktor yang dapat menentukan tingkat kepercayaan diri seseorang. ${ }^{15}$

\section{SIMPULAN}

Berdasarkan hasil uji korelasi antara kepercayaan diri dengan obesitas menunjukkan nilai $\mathrm{r}_{\mathrm{xy}}=-0,224$ dan $\mathrm{p}=$ 0,080. Hal ini menunjukkan bahwa terdapat hubungan yang tidak signifikan antara kepercayaan diri dengan obesitas. Sehingga, hipotesis bentuk $\mathrm{H}_{0}$ diterima, yakni tidak terdapat hubungan antara tingkat kepercayaan diri dengan obesitas pada siswa SMA Negeri 1 Manado. Jadi, obesitas tidak memiliki pengaruh terhadap kepercayaan diri siswa SMA Negeri 1 Manado.

\section{DAFTAR PUSTAKA}

1. Widyaningtyas D, Farid $\mathbf{M}$. Pengaruh Experiential Learning Terhadap Kepercayaan Diri dan Kerjasama Tim Remaja. Persona. 2014;3:237-46.

2. Martiyah L, Dewi FIR, Suyasa PTYS. Persepsi terhadap dukungan orang tua dan pembuatan keputusan karir remaja. Provitae. 2004;1:59-71.

3. World Health Organization. Obesity and overweight. 2015. Available from: http://www.who.int/mediacentre/factshee ts/fs311/en/

4. Riset kesehatan dasar. Riskesdas. 2011. Available from: http://labdata.litbang.depkes.go.id/menudownload/menu-download-laporan.

5. Yana DA. Dampak Psikologis Obesitas Pada Remaja. Available from: health.perempuan.com/dampakpsikologis-obesitas-pada-remaja/
6. Ashriati N, Alsa A, Suprihatin T. Hubungan Antara Dukungan Sosial Orang Tua dengan Kepercayaan Diri Remaja Penyandang Cacat Fisik Pada SLB-D YPAC Semarang. [cited 14 Oktober 2015]. Available from: http://fpsi.unissula.ac.id/images/proyeksi \%201\%20suprihatin.pdf

7. Farida NI. Upaya Meningkatkan Kepercayaan Diri Siswa Remaja Putri Yang Mengalami Pubertas Awal Melalui Layanan Penguasaan Konten Dengan Teknik Role Playing di Kelas VII SMP N 13 Semarang Tahun Ajaran 2013/2014 [Skripsi]. Semarang: Universitas Negeri Semarang; 2014.

8. Cribb VL, Haase AM. Girls feeling good at school, school gender environment, internalization and awareness of sociocultural attitudes associations with selfesteem in adolescent girls. Journal of Adolescence. 2016;46:107-14.

9. French SA, Perry CL, Leon GR, Fulkerson JA. Self-Esteem and Change in Body Mass Index Over 3 Years in a Cohort of Adolescents. Obesity Research. 1996;4(1):27-32

10. Strauss RS. Childhood Obesity And SelfEsteem. Journal of the American Academy of Pediatrics. 2000;1:1-5.

11. Jackson ES, Beeken RJ, Wardle J. Obesity, perceived weight discrimination, and physiological well-being in older adults in England.. Journal Obesity. 2015;23: 1105-11.

12. Griffiths LJ, Parsons TJ, Hill AJ. Selfesteem and quality of life in obese children and adolescents. International Journal of Pediatric Obesity. 2010;10:123.

13. Makinen M, Viertomies LRP, Lindberg N, Siimes MA, Aalberg V. Body dissatisfaction and body mass in girls and boys transitioning from early to midadolescence:additional role of selfesteem and eating habits. 2012. Available from:

http://www.biomedcentral.com/1471244X/12/35

14. Renman C, Engstrom I, Silfvedral SA. Mental health and psychosocial characteristics in adolescent obesity: a population-based case-control study. Acta Paediatr. 1999; 88:998-1003.

15. Hakim T. Mengatasi Rasa Tidak Percaya Diri. Jakarta: Puspa Swara, 2002. 